\title{
Peningkatan Kemampuan Keterampilan Basic Life Support (BLS) Melalui Pelatihan BLS Pada Perawat dan Bidan
}

\author{
Dwi Sulistyowati ${ }^{1}$, Sugiyarto ${ }^{2 *}$ \\ Jurusan Keperawatan, Poltekkes Kemenkes Surakarta \\ *Email: sugiy1077@gmail.com
}

\begin{abstract}
Background: In Hospital Cardiac Arrest (IHCA) is a major problem of patient safety and public health. the rescue action taken is Basic Life Support with CPR. BLS training needs to be provided to nurses and midwives in order to increase the ability of BLS skills. The purpose of this study was to analyze the effect of Basic Life Support (BLS) Training on the ability of BLS skills of Nurses and Midwives. Methods: This research is an experimental study with a Pre-Test-Post Test Group design approach through through testing the research hypothesis. The population of this study was nurses and midwives, amounting to 51 respondents with a total sampling technique so that the number of respondents was 51. Statistical tests in the paired group used the nonparametric Wilcoxon test. Results: Based on the Wilcoxon test results obtained a p value of 0,001 which means there is a difference between pre and post training, Conclusion: BLS training has an effect on improving the BLS skills of nurses and midwives. BLS skills training needs to be carried out on an ongoing basis so that nurses and midwives have good skills in conducting BLS.
\end{abstract}

Keywords: ability level, bls training, nurses and midwives

\section{PENDAHULUAN}

Kejadian henti jantung di dalam rumah sakit atau In Hospital Cardiac Arrest (IHCA) merupakan permasalahan utama keselamatan pasien dan kesehatan masyarakat. Sekitar 209.000 orang dewasa dan lebih dari 6000 anak dilakukan Cardio-Pulmonary Resuscitation (CPR) dengan IHCA Di Amerika Serikat setiap tahunnya. berbeda dengan Out Hospital Cardiac Arrest (OHCA) dewasa, yang sebagian besar disebabkan oleh dugaan etiologi jantung dan terjadi secara tidak terduga atau mendadak, sebagian besar IHCA adalah sekunder akibat gangguan pernapasan akut dan atau syok sirkulasi, dengan kemunduran progresif yang dapat diprediksi sebelum kejadian. Meskipun program pelatihan CPR cenderung berfokus pada CPR Out Hospital Cardiac Arrest (OHCA), akan tetapi perlu juga diberikan pada tenaga profesional di rumah sakit karena di dalam rumah sakit karakteristik pasien, penyelamatan dan sistem perawatan sangat berbeda dengan
Out Hospital Cardiac Arrest (Mancini et al., 2015).

Perawat dan Bidan merupakan bagian integral dari sistem perawatan kesehatan dan dianggap berpengetahuan luas dalam memberikan perawatan institusional kepada pasien. BLS merupakan keterampilan yang mendasar bagi tenaga kesehatan untuk menyelamatkan nyawa dan meningkatkan kualitas kesehatan masyarakat. Cardiopulmonary Resuscitation (CPR) adalah prosedur tindakan medis penting yang diperlukan bagi individu yang mengalami serangan jantung mendadak. Ini adalah kombinasi dari pemberian bantuan pernapasan dan kompresi dada yang diberikan kepada korban yang mengalami serangan jantung (Parajulee \& Selvaraj, 2011).

Kemampuan tenaga kesehatan dalam melakukan Cardio-pulmonary Resuscitation (CPR) secara sempurna hampir tidak mungkin dicapai mengingat 
situasi gawat-darurat yang menyertai CPR. Resusitasi di dalam RS seringkali tidak mencapai kualitas yang diinginkan, misalnya kompresi dada kurang dalam, pasien tidak ditempatkan pada alas yang sesuai standar, laju kompresi terlalu lambat, dan pemberian ventilasi terlalu tinggi (N.C.Sangamesh, K.C.Vidya, J.Pathi, \& A.Singh, 2017). Dalam melakukan kompresi memerlukan alat regulator kecepatan kompresi atau yang disebut dengan Neo Automatic Code. Dengan aplikasi ini mampu membantu perawat atau tenaga medis dalam melakukan kompresi sehingga akurasi kedalaman dan kecepatan bisa optimal (Darmawan, Sujianto, \& Rochana, 2018).

Kesalahan ini tidak hanya dilakukan oleh perawat atau bidan, namun juga oleh tenaga kesehatan lainnya seperti dokter umum, bahkan dokter spesialis (tidak termasuk dokter spesialis anestesi dan spesialis gawat darurat, yang sudah terspesialisasi dalam menangani situasi kritis). Pada beberapa rumah sakit atau institusi yang menyediakan sekolah keperawatan/kedokteran harus selalu menyelenggarakan pelatihan BLS selama masa pembelajaran Praktik klinik. Pelatihan sebelum memasuki fase klinik dan pelatihan penyegaran dapat membantu tenaga kesehatan dalam menangani situasi kritis di rumah sakit atau fasilitas kesehatan primer (Santos et al., 2015).

Pelatihan BLS membutuhkan praktik keterampilan atau psikomotor. Pada penelitian sebelumnya menunjukkan pentingnya pengulangan untuk mempertahankan pengetahuan dan keterampilan BLS setelah mendapatkan pelatihan awal. Pelatihan sistematis dan berulang dalam CPR adalah penting. untuk mengoptimalkan kepercayaan diri dalam kinerja CPR, dan berpotensi dalam menyelamatkan nyawa pasien yang mengalami cardiac arrest (Abolfotouh, Alnasser, Berhanu, Al-Turaif, \& Alfayez, 2017)

RSUD dr. Soeratno Sragen merupakan rumah sakit daerah yang sedang berkembang. Berdasarkan hasil wawancara dengan perawat RSUD dr. Soeratno Sragen, bahwa kejadian pasien dengan henti jantung sering terjadi. Dalam 1 bulan rata-rata ada 2 kasus pasien dengan henti jantung. Ruang perawatan intensive dan gawat darurat belum bisa maksimal untuk menangani pasien dengan kegawatan jantung, sehingga tenaga kesehatan khususnya perawat perlu meningkatkan pengetahuan dan ketrampilan dalam Penanganan pasien henti jantung, salah satunya adalah ketrampilan BLS. Tujuan dari penelitian ini adalah untuk menganalisis pengaruh pelatihan BLS terhadap kemampuan keterampilan Basic Life Support (BLS) pada Perawat dan Bidan di RSUD DR. Soeratno Gemolong Sragen.

\section{METODE PENELITIAN}

Penelitian ini merupakan penelitian eksperimental dengan menggunakan PreTes-Post Test One Group design. Jumlah responden dalam penelitian ini adalah 51 responden, dengan menggunakan total sampling. Waktu pelaksanaan penelitian ini adalah bulan Januari-Agustus 2017. Pengambilan data dilakukan dengan melakukan penilaian awal (pretest) dan setelah perlakuan dilakukan penilaian (posttest). Lembar penilaian berupa kuesioner.

Perlakuan dalam penelitian ini adalah pemberian pelatihan BLS kepada perawat dan bidan di RSUD Dr Suratno Gemolong Sragen. Pelatihan meliputi pemberian ceramah BLS dan simulasi 
praktik BLS. Kemudian data yang didapat menggunakan uji Wilcoxon.

dilakukan uji analisis dengan

\section{HASIL PENELITIAN}

Tabel 1. Distribusi Frekuensi Karakteristik Responden di RSUD Gemolong Sragen

\begin{tabular}{|c|c|c|}
\hline Variabel & Frek & Presentase (\%) \\
\hline \multicolumn{3}{|l|}{ Usia } \\
\hline Dewasa awal (18-40) & 44 & 86 \\
\hline Dewasa pertengahan $\quad(41-60)$ & 7 & 14 \\
\hline \multicolumn{3}{|l|}{ Jenis Kelamin } \\
\hline Perempuan & 47 & 92 \\
\hline Laki-laki & 4 & 8 \\
\hline \multicolumn{3}{|l|}{ Pendidikan } \\
\hline D3 & 46 & 90 \\
\hline S1 & 3 & 6 \\
\hline S1-Ners & 1 & 2 \\
\hline $\mathrm{S} 2$ & 1 & 2 \\
\hline
\end{tabular}

Tabel 2. Kemampuan Ketrampilan Basic Life Support (BLS) Perawat dan Bidan Sebelum Pelatihan di RSUD Gemolong Sragen $(\mathrm{n}=51)$

\begin{tabular}{|c|c|c|c|}
\hline Variabel & Mean & SD & Min-Max \\
\hline Kemampuan Ketrampilan Basic Life Support (BLS) & 50,41 & 11,80 & $40-70$ \\
\hline
\end{tabular}
sebelum Pelatihan adalah 50,41. Lembar

Tabel 3. Distribusi Frekuensi Tingkat Kemampuan Ketrampilan Basic Life Support $(B L S)$ Perawat dan Bidan sebelum Pelatihan di RSUD Gemolong Sragen ( $\mathrm{n}=$ 51)

\begin{tabular}{lcc}
\hline Variabel & Frek & Presentase (\%) \\
\hline Kemampuan Ketrampilan Basic Life Support (BLS) & & 0 \\
Baik & 0 & 35 \\
Cukup & 18 & 65 \\
Kurang & 33 & 0 \\
Jelek & 0 & \\
\hline
\end{tabular}

Tabel 3 menunjukkan bahwa tingkat sebelum Pelatihan sebagian besar adalah kemampuan ketrampilan Basic Life kurang (33 orang). Hasil penelitian Support (BLS) Perawat dan Bidan tentang tingkat kemampuan ketrampilan 
Basic Life Support (BLS) perawat dan bidan sebelum pelatihan dilihat dengan data interval dapat dilihat pada tabel 5 dan setelah dikelompokkan berdasarkan tingkatan dapat dilihat pada tabel 5.

Tabel 4. Kemampuan Ketrampilan Basic Life Support (BLS) Perawat dan Bidan setelah Pelatihan di RSUD Gemolong Sragen $(n=51)$

\begin{tabular}{lllll}
\hline Variabel & Mean & SD & Min-Max \\
\hline Kemampuan Ketrampilan Basic Life Support $($ BLS $)$ & 92,41 & 7,43 & $70-100$ \\
\hline Tabel 4 menunjukkan bahwa nilai & Life Support & (BLS) & Perawat dan Bidan \\
rata-rata kemampuan ketrampilan Basic & setelah Pelatihan adalah 92,41.
\end{tabular}

Tabel 5. Distribusi Frekuensi Tingkat Kemampuan Ketrampilan Basic Life Support (BLS) Perawat dan Bidan setelah Pelatihan di RSUD Gemolong Sragen ( $\mathrm{n}=$ 51)

\begin{tabular}{lcc}
\hline Variabel & Frek & Presentase (\%) \\
\hline Kemampuan Ketrampilan Basic Life Support $(B L S)$ & & \\
Baik & 48 & 94 \\
Cukup & 3 & 6 \\
Kurang & 0 & 0 \\
Jelek & 0 & 0 \\
\hline
\end{tabular}

Tabel 5 menunjukkan bahwa tingkat mengetahui hubungan antara karakteristik kemampuan ketrampilan Basic Life responden dengan tingkat kemampuan Support (BLS) Perawat dan Bidan ketrampilan Basic Life Support sebelum Pelatihan sebagian besar adalah (BLS)perawat dan bidan sebelum baik (48 orang). Hasil analisa data untuk pelatihan dapat dilihat pada tabel 6 .

Tabel 6. Pengaruh Pelatihan Ketrampilan Basic Life Support (BLS) Terhadap Tingkat Kemampuan Ketrampilan Basic Life Support $(B L S)$ Perawat dan Bidan di RSUD Gemolong Sragen $(\mathrm{n}=51)$

\begin{tabular}{|c|c|}
\hline Variabel & P Value \\
\hline Kelompok Pre-Post Pelatihan & 0,001 \\
\hline Tabel 6 menunjukkan bah & sia mem \\
\hline alue adalah 0,001 yang berarti ada & \\
\hline erbedaan antara pre dan post pelatihan & \\
\hline hingga dapat dikatakan ada pengaruh & ian yang dilal \\
\hline pemberian pelatihan ketrampilan Basic & Rajeswaran (2014) juga me \\
\hline Life Support (BLS) terhadap tingkat & bidan yan \\
\hline kemampuan ketrampilan Basic Life & di ruano \\
\hline Support (BLS) perawat dan bidan di & agian besar me \\
\hline RSUD Gemolong Sragen. & $\begin{array}{l}\text { ng dari } \\
\text { elamin }\end{array}$ \\
\hline EMBAHASAN & \\
\hline Penelitian menunjukkan & dimiliki adalah \\
\hline sebagian besar responden & D3 yaitu sebanyak 83 orang tetapi untuk \\
\hline
\end{tabular}


lama bekerja berbeda dimana pada penelitian Rajeswan (2014) rata-rata perawat dan bidan sudah bekerja lebih dari 3 tahun yaitu 64 orang.

Kemampuan perawat dan bidan sebelum dilakukan pelatihan adalah kurang dan memiliki nilai rata-rata yang rendah. Penelitian ini sejalan dengan penelitian yang dilakukan oleh (Rajeswaran \& Ehlers, 2014; Sankar, Vijayakanthi, Sankar, \& Dubey, 2013; Yunanto, Wihastuti, \& Rachmawati, 2017).

Kemampuan perawat dan bidan setelah dilakukan pelatihan adalah baik dan memiliki nilai rata-rata yang tinggi. Penelitian ini sejalan dengan penelitian yang dilakukan oleh (Rajeswaran \& Ehlers, 2014).(Sankar et al., 2013).(Yunanto et al., 2017). Penelitian menunjukkan bahwa ada pengaruh pelatihan ketrampilan basic life support (BLS) terhadap kemampuan ketrampilan basic life support (BLS) perawat dan bidan. Hal ini dapat diketahui dari uji statistik dimana $p$ value yang didapatkan $0,000 \quad(<0,05)$. Penelitian ini sejalan dengan penelitian yang dilakukan oleh Nori (2012) dimana dalam penelitian itu didapatkan bahwa nilai kemampuan ketrampilan basic life support (BLS) responden yang dilakukan pelatihan cardiopulmonary resuscitation (CPR) selama 4 hari mengalami peningkatan mean dibandingkan sebelum pelatihan.

Pengetahuan responden sebelum pelatihan rata-ratanya adalah 10,67 dan setelah pelatihan adalah 17,81 , sedangkan 10 hari setelah pelatihan adalah 15,25 dan 2 tahun setelah pelatihan adalah 12,86. Nilai kemampuan ketrampilan responden sebelum pelatihan rata-rata adalah 5,38 dan setelah pelatihan adalah 24,55, sedangkan 10 hari setelah pelatihan adalah
21,5 dan 2 tahun setelah pelatihan adalah 9,57. Hasil penelitian dari Nori juga menunjukkan bahwa pengetahuan dan kemampuan responden setelah mengikuti pelatihan Cardio Pulmonary Resuscitation (CPR) mengalami peningkatan yang sangat signifikan, tetapi nilainya turun setelah 10 hari meskipun penurunannya tidak signifikan. Nilai semakin turun setelah 2 tahun pelatihan, tetapi penurunan yang terjadi tidak lebih rendah dibandingkan dengan nilai sebelum pelatihan (Mokhtari Nori, Saghafinia, Kalantar Motamedi, \& Khademolv Hosseini, 2012).

Pelatihan

Cardiopulmonary

Resusitation (CPR) berpengaruh terhadap pengetahuan dan ketrampilan perawat dalam melakukan CPR (Rajeswaran \& Ehlers, 2014). Penelitian yang dilakukan terhadap 102 pasien ini menunjukkan hasil yang sejalan dengan penelitian yang dilakukan peneliti dan yang dilakukan oleh Nori (2012). Penelitian menunjukkan hasil bahwa pengetahuan responden ratarata sebelum pelatihan adalah 55,0 dan setelah pelatihan adalah 80,6 sedangkan 3 bulan setelah pelatihan adalah 70,7. Nilai rata-rata ketrampilan melakukan $\mathrm{CPR}$ sebelum adalah 9,42 dan setelah pelatihan adalah 78,31 sedangkan 3 bulan setelah pelatihan adalah 67,82. Hal ini menunjukkan bahwa nilai rata-rata pengetahuan dan kemampuan meningkat setelah pelatihan dan turun setelah 3 bulan pelatihan, tetapi penurunannya tidak seperti sebelum pelatihan. Tetap saja nilainya lebih tinggi dibanding dengan sebelum pelatihan.

Penelitian yang dilakukan oleh Sankar (2013) menunjukkan bahwa perawat yang bekerja di ruang pediatric dan mahasiswa yang akan lulus saat diberikan pelatihan CPR akan mengalami 
peningkatkan dalam kemampuan melakukan CPR. Akan tetapi kemampuannya akan menurun seiring dengan waktu, sehingga diperlukan pemberian pelatihan secara berkala. Sebelum dilakukan pelatihan rata-rata pengetahuan perawat adalah 6,6 dan mahasiswa keperawatan adalah 5,8. Nilai ini meningkat setelah dilakukan pelatihan yaitu 11,5 untuk perawat dan 11,3 untuk mahasiswa. Nilai turun setelah 6 minggu pelatihan tetapi penurunan tidak signifikan dan tetap lebih baik dibanding sebelum pelatihan yaitu 10,5 pada perawat dan 9,1 pada mahasiswa. Sejalan dengan tingkat pengetahuan, kemampuan melakukan CPR juga berbada. Sebelum dilakukan pelatihan rata-rata kemampuan perawat melakukan CPR adalah 3,2 dan mahasiswa keperawatan adalah 6,5. Nilai ini meningkat setelah dilakukan pelatihan yaitu 10,7 untuk perawat dan 10,1 untuk mahasiswa. Nilai turun setelah 6 minggu pelatihan tetapi penurunan tidak signifikan dan tetap lebih baik dibanding sebelum pelatihan yaitu 7,4 pada perawat dan 9,8 pada mahasiswa (Sankar et al., 2013).

Penelitian Nori (2012); Rajeswaran (2014); Oermann (2010); dan Sankar (2013) juga mendukung peraturan dimana perawat dan bidan, harus dilakukan pelatihan terkait cardiopulmonary resuscitation (CPR) atau basic life support setelah 2 tahun pelatihan. Hal ini dilakukan untuk selalu menjaga kemampuan dan ketrampilan perawat dan bidan dalam melakukan Cardiopulmonary Resuscitation (CPR) atau Basic Life Support (BLS). Penurunan kemampuan CPR merupakan salah satu dampak penurunan pengetahuan CPR setelah dilakukan pelatihan tanpa adanya maintenance. Oleh karena itu pengetahun tentang CPR merupakan faktor utama dalam melakukan ketrampilan CPR dengan benar. Pencegahan terhadap penurunan kemampuan perawat dan bidan dalam melakukan CPR dapat dilakukan pelatihan secara berkala mengenai pelaksanaan CPR setidaknya minimal 2 tahun sekali (Mokhtari Nori et al., 2012; Rajeswaran \& Ehlers, 2014; Sankar et al., 2013).

Penelitian yang dilakukan oleh Suharso (2016) juga sejalan dengan hasil penelitian dari peneliti dimana pelatihan tindakan resusitasi jantung paru (RJP) yang diberikan kepada siswa SMA memiliki pengaruh pada tingkat pengetahuan dan ketrampilan siswa dalam melakukan RJP. Tetapi pada penelitian yang dilakukan oleh Suharso pelatihan RJP yang diberikan kepada masyarakat awam lebih berfokus kepada pemberian kompresi dada tanpa memberikan ventilasi karena kemampuan mereka yang sebelumnya memang belum terpapar sama sekali dengan tindakan RJP. Penelitian yang dilakukan oleh Suharso (2016) mendapatkan hasil rata-rata pengetahuan sebelum pelatihan adalah 6,94 dan setelah pelatihan adalah 9,13 (Suharsono \& Fikriana, 2016).

Pelatihan BLS selama satu hari sangat efektif untuk tenaga kesehatan di rumah sakit umum daerah di Indonesia dan nilai post-test memiliki hubungan yang erat dengan ujian praktik, tidak hanya ujian RJP pada dewasa tetapi juga ujian RJP pada anak. BLS adalah keterampilan penting yang memegang peran kunci bertahan terhadap serangan jantung mendadak dan beberapa kasus darurat lainnya seperti adanya sumbatan nafas. Keterampilan tersebut sangat penting dimiliki oleh setiap warga negara dewasa terutama tenaga kesehatan di Rumah Sakit. Meskipun memiliki 
berbagai pengalaman pendidikan, jenis kelamin dan pelatihan sebelumnya, pelatihan bantuan hidup dasar selama satu hari memiliki dampak yang signifikan dalam meningkatkan pengetahuan dan keterampilan dalam kelompok tenaga kesehatan di berbagai rumah sakit umum daerah di Indonesia. Oleh karena itu, metode pelatihan bantuan hidup dasar tunggal selama satu hari ini memberikan kesempatan untuk dikembangkan sebagai metode pengajaran standar yang akan diterapkan di Indonesia (Nugroho et al., 2018).

Hasil studi menunjukkan bahwa program pelatihan berulang dapat meningkatkan sikap terhadap kinerja RJP dan penggunaan AED. Jumlah kursus pelatihan BLS yang dihadiri sebelumnya berkorelasi dengan level baik sikap dan perhatian, sehingga individu dengan lebih banyak pengalaman pelatihan memiliki sikap yang lebih baik berkenaan dengan CPR dan AED dibandingkan individu dengan pengalaman terbatas. Pelatihan sistematis dan berulang dalam CPR adalah penting. Organisasi penyedia layanan kesehatan dan penyedia pelayanan individu keduanya harus terlibat dalam memastikan bahwa kursus tersebut dilakukan dan diselesaikan, untuk mengoptimalkan kepercayaan diri dalam kinerja CPR, dan berpotensi menyelamatkan nyawa (Abolfotouh et al., 2017).

\section{KESIMPULAN DAN SARAN}

Berdasarkan hasil penelitian, maka dapat ditarik kesimpulan bahwa terdapat pengaruh pemberian pelatihan ketrampilan Basic Life Support (BLS) terhadap tingkat kemampuan ketrampilan Basic Life Support (BLS) perawat dan bidan di RSUD Gemolong Sragen.
Pelatihan ketrampilan Basic Life Support (BLS) harus dilakukan kepada perawat, bidan agar mereka memiliki ketrampilan yang baik dalam melakukan Basic Life Support (BLS) atau CPR. Pelatihan keterampilan Basic Life Support (BLS) perlu dilakukan secara berkelanjutan dengan waktu minimal pengulangan adalah 2 tahun.

\section{DAFTAR RUJUKAN}

Abolfotouh, M. a., Alnasser, M. a., Berhanu, A. N., Al-Turaif, D. a., \& Alfayez, A. I. (2017). Impact of basic life-support training on the attitudes of health-care workers toward cardiopulmonary resuscitation and defibrillation. BMC Health Services Research, 17(1), 1-10. https://doi.org/10.1186/s12913-0172621-5

Darmawan, R. E., Sujianto, U., \& Rochana, N. (2018). Effects of Neo Automatic Code on the Accuracy of Chest Compression Depths in Cardiac Arrest Patients. Hiroshima J. Med. Sci, 67(024), 161-165.

Mancini, M. E., Diekema, D. S., Hoadley, T. a., Kadlec, K. D., Leveille, M. H., McGowan, J. E., ... Sinz, E. H. (2015). Part 3: Ethical issues: 2015 American Heart Association guidelines update for cardiopulmonary resuscitation and emergency cardiovascular care. In Circulation (Vol. 132). https://doi.org/10.1161/CIR.0000000 000000254

Mokhtari Nori, J., Saghafinia, M., Kalantar Motamedi, M. H., \& Khademolv Hosseini, S. M. (2012). 
CPR training for nurses: How often is it necessary? Iranian Red Crescent Medical Journal, 14(2), 103-106.

N.C.Sangamesh, K.C.Vidya, J.Pathi, \& A.Singh. (2017). Nickel Titanium Rotary Instruments: Development of the Single-File Systems. Journal of International Society of Preventive and Community Dentistry, 8(5), 7181.

https://doi.org/10.4103/jispcd.JISPC D

Nugroho, N. .., Azalea, S., Widyaningsih, Y. A., Rahmapuspita, Damanik, J., Suprapto, A. P., ... Jamaluddin, A. (2018). Efektivitas Bantuan Hidup Dasar Untuk Teaga Kesehatan Indonesia. ARKAVI [Arsip Kardiovaskular Indonesia), 3(1), 200-204.

https://doi.org/10.22236/arkavi.v3i1. 3689

Parajulee, S., \& Selvaraj, V. (2011). Knowledge of Nurses towards cardio-pulmonary resuscitation in a tertiary care Teaching Hospital in Nepal. Journal of Clinical and Diagnostic Research, 5(8), 15851588.

Rajeswaran, L., \& Ehlers, V. J. (2014). Cardiopulmonary resuscitation knowledge and skills of registered nurses in Botswana. Curationis, 37(1), 1259. https://doi.org/10.4102/curationis.v3
$7 \mathrm{i} 1.1259$

Sankar, J., Vijayakanthi, N., Sankar, M. J., \& Dubey, N. (2013). Knowledge and skill retention of in-service versus preservice nursing professionals following an informal training program in pediatric cardiopulmonary resuscitation: A repeated-measures quasiexperimental study. BioMed Research International, 2013. https://doi.org/10.1155/2013/403415

Santos, S. V., Margarido, M. R. R. a., Caires, I. S., Santos, R. a. N., Souza, S. G., Souza, J. M. a., ... Pazin-Filho, a. (2015). Basic life support knowledge of first-year university students from Brazil. Brazilian Journal of Medical and Biological Research, 48(12), 1151-1155. https://doi.org/10.1590/1414431X20154667

Suharsono, T., \& Fikriana, R. (2016). Effect of Tutorial Teaching Method for Knowledge and Skill of CPR. Jurnal Keperawatan, 7(2), 156-162. https://doi.org/10.22219/JK.V7I2.394 5

Yunanto, R. A., Wihastuti, T. A., \& Rachmawati, S. D. (2017). Perbandingan pelatihan RJP dengan mobile application dan simulasi terhadap pengetahuan dan keterampilan melakukan RJP. NurseLine Journal, 2(2), 183-193. 